
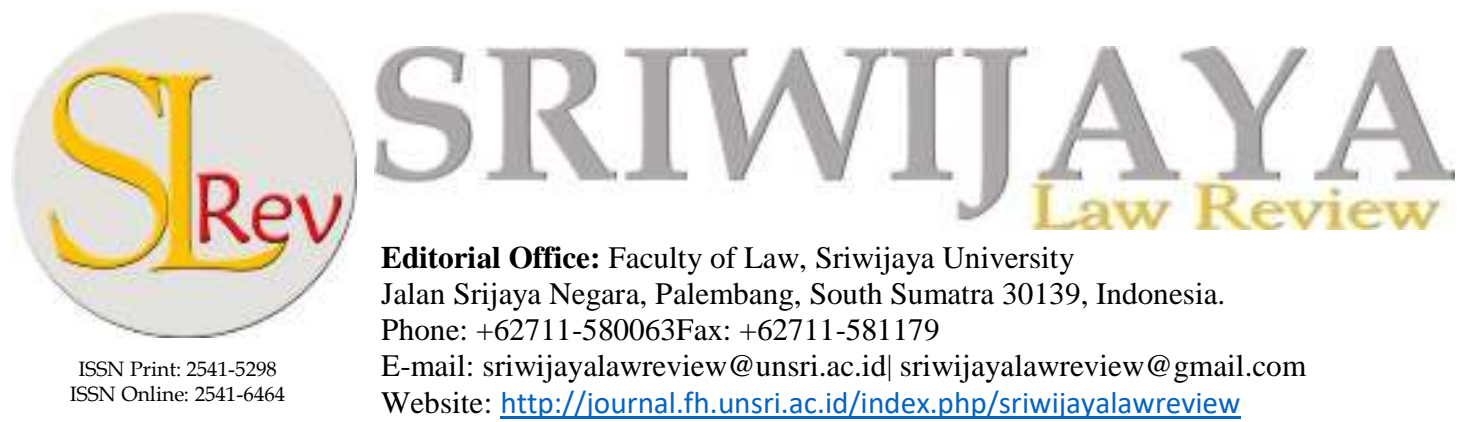

Editorial Office: Faculty of Law, Sriwijaya University

Jalan Srijaya Negara, Palembang, South Sumatra 30139, Indonesia.

Phone: +62711-580063Fax: +62711-581179

E-mail: sriwijayalawreview@unsri.ac.id| sriwijayalawreview@gmail.com

Website: http://journal.fh.unsri.ac.id/index.php/sriwijayalawreview

\title{
The Establishing Paradigm of Dominus Litis Principle in Indonesian Administrative Justice
}

\author{
Soehartono, ${ }^{\mathrm{a}}$ Kukuh Tejomurti, ${ }^{\mathrm{a}^{*}}$ Arsyad Aldyan, ${ }^{\mathrm{a}}$ and Rachma Indriyani ${ }^{\mathrm{b}}$ \\ $a^{*}$ Faculty of Law, Universitas Sebelas Maret, Indonesia. Corresponding author: kukuhmurtifhuns@staff.uns:ac id \\ b School of Law, Universiti Utara Malaysia, Malaysia.
}

\begin{tabular}{|c|c|}
\hline Article & Abstract \\
\hline $\begin{array}{l}\text { Keywords: } \\
\text { Dominus Litis; Dispute } \\
\text { Accomplishment; Judge } \\
\text { Paradigm; State } \\
\text { Administrative Justice. } \\
\text { Article History } \\
\text { Received: Sep 2, 2020; } \\
\text { Reviewed: Jan 16, 2021; } \\
\text { Accepted: Jan 28, 2021; } \\
\text { Published: Jan 31, 2021. } \\
\text { DOI: } \\
\text { 10.28946/slrev.Vol5.Iss1. } \\
\text { 877.pp42-55 }\end{array}$ & $\begin{array}{l}\text { This study aimed to analyse a shifting paradigm of Dominus Litis (judge } \\
\text { activeness) in the Indonesian state administrative justice. This principle } \\
\text { emphasises that judges expand the paradigm that judges are not limited to } \\
\text { being used in processes regulated in law. However, judges need to actively } \\
\text { develop the paradigm to make legal discoveries oriented towards substantive } \\
\text { justice and expand the paradigm from merely resolving disputes } \\
\text { positivistically to resolving conflicts with paradigms. Legal realism and } \\
\text { sociological jurisprudence to create substantive justice. This paper uses the } \\
\text { normative research method, with a statutory approach and case approach by } \\
\text { analysing two decisions of state administrative court judges. The result } \\
\text { showed that Dominus Litis in the dispute's accomplishment is not limited to } \\
\text { the implementation of juridical-legal positivism factors, but on how judges } \\
\text { use their mindset to provide ideal decisions and conduct legal reasoning use } \\
\text { socio-legal and socio-cultural paradigms. The development of demands for } \\
\text { justice has also experienced a paradigm shift of justice. It requires the } \\
\text { principle of an active judge who always follows developments in public } \\
\text { policy, such as the principle of sustainable development related to } \\
\text { environmental and natural resource issues, and finding the legal material } \\
\text { truth. }\end{array}$ \\
\hline \multicolumn{2}{|c|}{$\begin{array}{l}\text { (C)2021; This is an Open Access Research distributed under the term of the Creative Commons Attribution License } \\
\text { (https://Creativecommons.org/licences/by/4.0), which permits unrestricted use, distribution, and reproduction in } \\
\text { any medium, provided the original works is properly cited. }\end{array}$} \\
\hline
\end{tabular}

\section{INTRODUCTION}

An Administration Court is a government institution with authority to adjudicate legal disputes between parties. It also carried out the administration of justice in civil, criminal, and bureaucratic matters based on the rule of law. Therefore, there is a need to pay serious attention to its existence because the ruling offers solutions to justice seekers under the repressive and preventive objectives. The first objective is to annul verdicts deemed contrary to applicable laws and principles of good governance. Simultaneously, the second involves decisions in the form of administrative rules of law, which serves as guidelines for the State Administration Agencies or 
Officials. The court was established to provide legal protection for the people disfavored by the State Administrative Officers. ${ }^{1}$

Judges need to actively discover material truths as desired by the state administrative justice and the Law on Judicial Powers, including its practice in dispute accomplishment. Their activeness greatly aids the community to get justice, which is following judges' duties. These include examining, deciding, and settling disputes, particularly during the examination of Administrative Decrees issued by State Agencies or Officials, contrary to the prevailing laws and general principles of good governance. Presently, the decrees reviewed by the judge have experienced extensive changes, such as the issuance of Law No. 30 of 2014 concerning Government Administration. Besides, they are implemented by executives, legislative, and judiciary.

The enactment of Law No. 30 of 2014 concerning Government Administration has brought about inevitable consequences involving extending the administrative court's absolute competence and examining government actions. ${ }^{2}$ According to Wahyu Beni Mukti, State Administrative Justice, which is an element of rechtsstaat, is intended to legally protect citizens for governmental actions in the field of State Administration. ${ }^{3}$

The State Administrative Decree's symbolic meaning implies that the judges need to be actively involved in dispute accomplishment brought before the court. Concerning the review of State Administrative Decrees, they do not only carry out their duties based on applicable laws, which is one of the guidelines for dispute accomplishment. Laws cannot accommodate and regulate all the interests and needs of humans in society, and sometimes they are unclear and outdated. Consequently, their tasks are getting more rigid and more difficult because they do not just apply these laws to concrete problems. The restraining classic views need to be released by the judges. According to Montesquieu, they are only the law's mouthpiece (the judge as la bouche de la loi). ${ }^{4}$ This view is unable to proffer solutions to increasingly complex legal issues, including the constantly evolving law.

Portalis disagreed with this perspective and reported that people are entirely aware that the teachings of trias politica are too simple to be applied in practice. Due to its impossibility and an unavoidable fact, the judge's task is not merely to apply the legal text automatically. Irrespective of this fact, people desire a comprehensive law; therefore, it is immediately applied, and several random questions emerge. ${ }^{5}$

Based on these circumstances, judges need not solely rely on the law as a basis for settling disputes at hand. Instead, they have to actively, creatively, and innovatively discover measures according to community justice. They are described as unqualified when the ruling is based on

\footnotetext{
Francisca Romana, 'Authority Of The Judge Of Administrative Court To Revise The Government Official Decision', Journal of Legal, Ethical and Regulatory Issues, 21.Special Issue (2018), 1.

2 Firzhal Arzhi Jiwantara. Et.All, 'The Extension Of Absolute Competence Of State Administrative Court After The Enactment Of Act Number 30 Of 2014 On Government Administration In Indonesia', Journal of Legal, Ethical and Regulatory Issues, 21.2 (2018), 1.

3 Wahyu Beny. Et.All, 'Law Politic Of Administrative Court Judicature In Indonesia', International Journal of Law Reconstruction, III.1 (2019), 48.

4 Soedikno Mertokusumo, Peneтиan Hukum Sebuah Pengantar (Yogyakarta: Universtas Atma Jaya, 2010).

5 Ridwan, 'Hukum Dan Perubahan Sosial: (Perdebatan Dua Kutub Antara Hukum Sebagai Social Control Dan Hukum Sebagai Social Enginnering)', Jurnal Jurisprudence, 6.1 (2017), 28-39.
} 
only the law, which leads to harsh criticism, which is also a constructive input complementing the decision to either gain a stand or be accepted in society. It does not imply the need to negate the ancient legal system. Therefore there needs to be a change in the judge's mindset. Their decisions need to reflect justice, as well as explore and understand the legal implications. As mandated in Law No.48 of 2009 concerning Judicial Power, Article 5 paragraph (1) states that constitutional judges are required to explore, adapt, and understand the implications of law and justice in the society. Furthermore, the principle of curia novit or perceived as people who understand the law need not be forgotten because this is considered inherent in them.

Law No. 30 of 2014 regarding Government Administration has led to a broader change in the State Administrative Court's authority. Therefore there is a need for the judges to be more active, creative, and innovative. They do not reveal the provisions of applicable laws; instead, they are guided by these regulations, which is the only basis for passing a verdict. Apart from ensuring a stable correlation between the plaintiff and the defendant, it is time to experience a shift in meaning and purpose to discover material truths. However, serious attention needs to be paid to the principle of judges' activeness (dominus litis) concerning ways or manners to construct and interpret it, regarding the fact that they are expected to be thorough and profound in disputes accomplishment.

\section{RESEARCH METHODS}

This study uses a doctrinal approach or also referred to as the normative legal approach. Existing data are linked to each other through library research, reviewed and interpreted also analysed to conclude. Normative research methods are research that refers to legal norms contained in legislation and court decisions. Resources are obtained from literature or secondary data, ${ }^{6}$ which consists of primary legal and secondary legal materials. Primary legal materials include basic norms and rules, such as the 1945 Constitution, Law No. 48 of 2009 on Judicial Power, Law No. 30 of 2014 regarding Government Administration, Law No. 5 of 1986 amended to Law No. 9 of 2004 concerning State Administrative Justice and the second amendment of Law No. 51 of 2009). Also, decisions of the Administrative Court in the environmental case will enrich the primary legal materials. Secondary legal materials are documents other than legal products that provide additional information on primary legal materials. Those legal materials may include constitutional interpretation literature, research results, legal expert opinions and scientific articles related to interpretation in the court's decision. The data obtained will be analysed by qualitative descriptive methods.

\section{ANALYSIS AND DISCUSSION \\ Dominus Litis Principle in Disputes Accomplishment}

The study is centred on dominus litis in dispute accomplishment of the state administration, and it is essential. It is because the ruling of an administrative court is a means of controlling government actions in carrying out its duties. Besides, this ruling or decision provides legal protection for citizens or entities whose rights or interests are impaired. Consequently, the law

\footnotetext{
6 Amiruddin and Zainal Asikin, Pengantar Metode Penelitian Hukum (Jakarta: Rajawali Pers, 2012).
} 
and society are continually evolving; emerging problems are getting more complex and increasingly difficult to resolve. Critics and public dissatisfaction with the judge's ruling were increasingly felt because the defendant did not get the expected justice. The existence of judges' activeness or dominus litis principle in the legal world is always questionable.

Dominus Litis in disputes accomplishment is not only limited to the application of the law. However, it needs to be interpreted based on the judges' mindset to pass a definitive verdict for both parties. In this regard, Carbonnier reported that for thousands of years, there had been high demands for intellectual judges. ${ }^{7}$ Satjipto Rahardjo, a Central Java jurist, stated that the court needs major reconstruction; however, it needs to be deconstructed before it is implemented. In this instance, deconstruction involves getting rid of the ancient ways of carrying out certain court activities, starting with the judge's mentality and attitude towards their work. It merely implies that their behaviours and thoughts are a significant priority that needs to change. Presently, in order to restore a "credible" and "reliable" Supreme Court, "human change" is more relevant than "legal change". 8

Soetandyo Wignjosoebroto reported that deconstruction relating to the reinterpretation of an existing legal norm is based on the text's free play. Conversely, immediately a text of law or judge's decision is formulated, it is freed from the original purpose, each has its biography. It is expected of subsequent generations to change the text's contents through various opportunities relating to ijtihad, while the previous ones cannot prevent this alteration. ${ }^{9}$ Another research stated that the call for reformation is powerful and usually raised in Indonesia, although the result is invisible. It is because the effort to reform only occurs at the level of positive legislative norms and never dived into attempts to deconstruct and reconstruct the entire national legal system based on new non-positivist and nondoctrinal paradigms that have to be preceded by a sociopolitical movement. ${ }^{10}$

Anthon F. Susanto stated that the adoption of deconstruction as a method of interpreting the law is not a new thing, despite not being common. Some postmodernism features, such as critical legal studies or feminist jurisprudence, are used to interpret the law by adopting the deconstruction method. According to the critical legal studies, deconstruction is a reversal carried out to detect hidden meanings, which are sometimes privileged by history. For example, established legal doctrines tend to be taken for granted. Feminist Jurisprudence uses it to reverse the paradigm that has always favoured discourse on men over women. It is due to the dominance of the logical analysis (deduction) adopted. ${ }^{11}$

Dominus Litis in disputes accomplishment is evident in Law No. 48 of 2009 concerning Judicial Power Article 5 paragraph (1), Soedikno Mertokusumo reported that it is assumed that the law exists, however, it is hidden. Therefore it has to be excavated to the surface.

\footnotetext{
Achmad Ali, Menguak Tabir Hukum (Bogor: Ghalia Indonesia, 2008).

8 Anthon F. Susanto, Wajah Peradilan Kita Konstruksi Sosial Tentang Pnyimpangan. Mekanisme Kontrol Dan Akuntabiltas Peradilan Pidana (Bandung: PT. Refika Aditama, 2004).

9 Soetandyo Wignjosoeborot, Pergeseran Paradigma Dalam Kajian-Kajian Ilmu Sosial Dan Hukum (Malang: Setara Press, 2013).

10 Ahmad Namlis, 'Dinamika Implementasi Penyelenggaraan Pemerintahan Daerah', Jurnal Kajian Pemerintah: Journal Of Government, Social And Politics, 4.1 (2018).

11 Anthon F. Susanto, Ilmu Hukum Non Sistematik Fondasi Filsafat Pengembangan Ilmu Hukum Indonesia (Yogyakarta: Genta Publishing, 2010).
} 
Consequently, the law exists and needs to be explored, sought, and discovered. Scholten reported that human behaviour is guided by the law, which needs to be dug up, sort for, or discovered (Soedikno Mertokusumo, 2010). ${ }^{12}$

The term "judicial activism" is exceptionally well-known in the legal system. Judges in the United States adhere to this doctrine, and rulings are passed to protect minorities. In Indonesia, judicial practices related to complex problems must bring on the lawfulness, or it is adopted to broaden the perspective that law is always evolving, dynamically based on society's development. This paper will analyse how the development of the dominus litis principle paradigm in state administrative judges and illustrate what factors are used by judges in legal considerations to develop this principle.

\section{The Establishing Paradigm}

It is essential to analyse the shift in the emergence of new ideas, referred to as postmodernists from the last decades of the 20th century to the beginning of the 21 st century. ${ }^{13}$ The shift from the modern to the post-modern era is an erosive process. Two reasons back up this perspective, firstly, it occurred as a process of "replacement" in as much as modernism had partially fulfilled its promises. Secondly, as an aspect of "obsolescence," it is unable to accomplish certain obligations.

The Administrative Court in Indonesia is inseparable from the mandates of state administration to give the people a sense of justice. ${ }^{14}$ The Institution of State Administrative Court is an independent authority under the sovereignty of the Supreme Court. ${ }^{15}$ As stated earlier, the duties of judges in resolving disputes are increasingly becoming complex. In addition, their decisions have received harsh criticism because they do not reflect justice. In examining and resolving disputes, they need not rely solely on the old or cliché way of imposing law and logic, which is identical to being linear, mechanistic, and predictable. However, the outcome is the passing of a verdict that is inclined towards procedural justice according to the authorities' desires. It is high time this method is abandoned, and judges need not only be shackled by the law's provisions and use of ratio. Satjipto Rahardjo reported that legal experts detect reality from the optical side of the law, regulations, final schemes, concepts, and definitions, as previously reported. However, such a method deprives the law of its habitual and cultural roots. ${ }^{16}$ This mindset reached its peak in the 19th century and was similar to the 14th century Cartesian method of reasoning. Therefore, this approach and mindset have to be abandoned because the law is dynamic and continues to evolve due to the development of science and judicial practice becoming increasingly complex.

According to Satjipto Rahardjo, the judges' legal method in Indonesia, which involves the general way of learning in law faculties, is dominated by "rule-based thinking" or "book-rule

12 Mertokusumo, S. (2010). Hukum acara perdata Indonesia. Universitas Atma Jaya Yogyakarta..

13 Otje Salman dan Anthon F Susanto, Teori Hukum (Mengingat, Mengumpulkan, Dan Membuka Kembali) (Bandung: Refika Aditama, 2004).

14 Miftah Sa'ad, 'The Schorsing in Implementation of Administrative Decision That Endanger the Environment by Administrative Court', Nagari Law Review, 1.2 (2018), 180.

15 Ruslin, 'An Existence of State Administration Court in Establishing Good Governance', Aloha International Journal of Multidisciplinary Advancement (AIJMU), 1.1 (2019), 2.

16 Satjipto Rahardjo, Lapisan-Lapisan Dalam Studi Hukum (Malang: Bayumedia Publishing, 2008). 
model". This type of learning ignores the behavioural aspect of the law, irrespective of the fact that this factor is extremely prominent in practice. The legendary Supreme Court Judge of the United States, Oliver We."ell Holmes, reported it in another dimension: "the life of the law is not based on logic. It encompasses a series of experiences. The necessities of the time, the prevalence of moral and political theories, intuitions of avowed public policies, including the prejudices judges share with their colleagues, have a good impact unlike the syllogism involved in determining the rules by which men need to be governed." In this instance, the behaviour is formulated based on the judges' experiences. ${ }^{17}$

They need to abandon linear and mechanistic mindsets immediately, prioritise statutory provisions, and logic similar to linear reasoning. According to Paul Scholten, this way of thinking is referred to as "hanteren van logicche figuren" (dealing with logical problems) due to the extraordinary successes and developments recorded in natural science between the 18th and 19th centuries. ${ }^{18}$ Those judges that rely on logic and written regulations and are shackled by the dominance of positive law tend to pass verdicts that apart from being criticised, do not reflect society's justice value. The law is not perceived or considered the only guideline to impose a decision. Therefore a legal basis needs to be discovered. The judge needs to get out of the shackles that emphasise procedural rather than substantive justice.

Lily Rasyidi stated that most Indonesians' legal problems need to be improved, considering its several weaknesses or unsatisfactory justice value (not aspirational) by enacting new laws. This process was accomplished by carrying in-depth studies on problematic legislation and legal findings (rechtsvinding) by the law enforcers (judges). Efforts are made based on a flow approach or positive law of science, and this only analyses the periphery of these issues and not their root causes. The material review of statutory regulations (constitutional and judicial review) based on the Constitutional and the Supreme Courts leads to misconception and inappropriate application. The flow of positive law is dynamic, therefore, to resolve the significant causes of these problems, there is a need to adopt a modern theoretical and philosophical approach that is inseparable from the cultural roots and unique character of the nation. The legal theory of development is reviewed again to achieve specific objectives and resolve ongoing problems. ${ }^{19}$

The principle of the judges' activeness (dominus litis) need not remain silent. Instead, it needs to create a balanced position between the plaintiff and the defendant during the settling of a state administrative dispute. It is also related to the issuance of Law No. 30 of 2014 concerning Government Administration, which gives the State Administrative Court more and due to the changes in its decrees, expansion of the disputes' subject and object, and the increasingly complex problems within the state. The judge activeness (dominus litis) needs to adapt to these developments. Besides creating a balanced position between the plaintiff and the defendant, it also needs to provide justice as the community desires. Judges need not only rely on their IQ (intellectual quotient); however, they also need to adhere to the development of EQ (emotional

17 Sri Rahayu Oktoberina dan Niken Savitri, Butir-Butir Pemikiran Dalam Hukum Memperingati 70 Tahun Prof. Dr. B. Arief Sidharta. SH (Bandung: Refika Aditama, 2008).

18 Bernadinus Steni, 2011, Hukum Progresif, Pluralisme Hukum, dan Gerakan Masyarakat Adat, Epistema Institute: Jakarta

19 Sinta Dewi, Tinjauan Kritis Atas Perkembangan Hukum Seiring Perkembangan Masyarakat Di Indonesia (Bandung: Widya Padjadjaran, 2009). 
quotient) and SQ (spiritual quotient) thoughts. Danah Zohar and Ian Marshall reported that the easiest way of thinking is similar to a machine, a symbolism of IQ (intellectual quotient). However, it was measured by the standard IQ for a long time, called serial thinking or the simplistic model of thinking, which is defined as the ability to think straight and logically, without involving emotions. It is appropriate, although it does not describe or represent the entire human way of thinking. It was rather complemented by EQ (emotional quotient), which is an associative way of reasoning. Finally, SQ (spiritual quotient) is the perfect way of thinking (ultimate intelligence), and it is referred to as unitive thinking, which generates meaning-giving intelligence in the context of jumping out of bonds (transformative). Consequently, another form of SQ is creative, insightful, and intuitive thinking. ${ }^{20}$

Satjipto Rahardjo confirms Danah Zohar and Ian Marshall's opinion, which stated that rational thinking is logical, linear, serial, and has no sense of involvement (dispassionate). Furthermore, this type of reasoning does not consider the environment or habitat. However, towards the end of the 20th century, a model emerged which involves the dimension of depth, namely searching for the meaning and hidden values of the object being studied. It is referred to as spiritual intelligence, which is not rule-bound or contextual, rather it desires to get out of the existing situation to seek the truth, meaning or deeper values. It is stiff, affects certain circumstances, despite being creative and liberating. Following creativity, it functions by breaking existing standards (rule-breaking) and simultaneously enacting new ones (rule-making). This intelligence also does not get rid of IQ and EQ, and preferably it accomplishes a perfect level. ${ }^{21}$

Dominus Litis in disputes accomplishment is evident in the development of thoughts outlined in the judges' decisions, such as the judicial ruling of the Jakarta State Administrative Court No. 094/G/1994/IJ.TUN.JKT and the Supreme Court. The two rulings exhibit the judges' courage in accomplishing state administrative disputes, apart from opposing the authority and ignoring the law that serves as the basis for passing verdicts. It seems as though the judges' have experienced a fundamental shift or change and seek societal norms as the basis for the decisions or guidelines. The judges' panel reported that the cancellation of the Tempo SIUPP (press issuance business license) was legally flawed, both formally and materially. The Decree of the Information Minister contradicts the applicable law, namely the morale of the Main Press Law No. 11 of 1966, which is an amendment of Law No. 21 of 1982, Article 13, and the hierarchy in legislation. $^{22}$

The philosophy of dominus litis is that the legal considerations serve as the basis for decision-making and the reality of social dynamics, which aids in resolving the dispute. It is following judges' duties in the 21st century, which relates to the evolving law towards society. The issuance of Law No. 30 of 2014 concerning Government Administration reported that the judges are burdened with heavy and diverse tasks. Therefore, there needs to be severe changes and shifts, and they need to possess the courage to realise substantial justice as the community desires. As legal actors, judges are critical and need to have the courage to make confident

\footnotetext{
20 Satjipto Rahardjo, Biarkan Hukum Mengalir Catatan Kritis Tentang Pergulatan Manusia Dan Hukum (Jakarta: Buku Kompas, 2007).

21 Jimly Asshiddiqie, Gagasan Konstitusi Sosial (Jakarta: LP3ES, 2015).

22 A. Muhammad Asrun, Krisis Peradilan Mahkamah Agung Di Bawah Soeharto (Jakarta: ELSAM, 2004).
} 
choices when passing their verdicts. According to the Judge's Decision at the Yogyakarta State Administrative Court, it seems as though there is a shift in their mindset, as stated in Law No. 03/G.TUN/2000/PTUN Yogyakarta. Additionally, before passing a verdict, they need to examine their conscience, thereby ensuring the community accepts the ruling because the judge observes, feels, and can identify the realities in the society, as stipulated in Decision No. 4/G/2009/PTUN/Semarang. The panel of judges needs to consider society before passing their verdicts. For example, they need to assess the fact that the establishment of a cement factory has to either eliminate or reduce the sources of water used by farmers for planting crops. They need to be able to explore societal life to use it as the basis for decision-making.

The judges' activeness (dominus litis) under the issuance of Law Number 30 of 2014 concerning Government Administration is increasingly needed because this is not only a source of legal material for the state administrative court. It also alters its definition, thereby broadening the authority of the Administrative Justice in the country. According to Article 1, paragraph (2): "Government Administrative Decisions, also known as State Administration, are consequently referred to as written laws issued by Government Agencies or Officials." Article 87 states that: "based on applicable law, the State Administration Decree referred to in Law No. 5 of 1986 amended in Law No. 9 of 2004 and Law Number 51 of 2009, has to be interpreted, as a) written decision that includes concrete actions, b.) Decisions of Administrative Agencies or Officials and other state administrators of the executive, legislature, judiciary, c.) Based on statutory provisions and Asas-Asas Umum Pemerintahan Yang Baik (General principles of good governance), d.) It is final in a broader sense, e.) Decisions with the potential to raise legal consequences, and f.) Decisions applied to Citizens.

\section{The Legal Philosophy of Dominus Litis Principle}

The principal objective of Dominus Litis, which is to balance the position of the defendant and the plaintiff, is a form of the principle of equality before the law used in the preparatory examination. This principle teaches the court to provide justice for the plaintiff, namely procedural justice so that the plaintiff's position is equal to that of the defendant. Ubi societas ubi ius, which means that in society, indeed there are laws. Not only written law is made by the ruler or legislature but also laws that live and develop in society or unwritten law. Eugen Ehrlich states that the centre of gravity of legal development lies not in legislation, juristic science, or judicial decision but society. He revealed that the concept of living law comes from two elements: legal history and jurisprudence, which is the use of precedents and written comments and Living law that grows out of people's habits.

We can understand that living law is the developing values and ideas or habits that live and influence society's development. Concerning the judge's decision, the concept of living law affects the morals and values of a judge's life, which will be seen in the decision's legal considerations.

The legal positivism paradigm by the judge will cause a formal, and positivistic decision that is under the content or formulation in the applicable legislation. In such circumstances, the judge acts only as a "statute mouthpiece." The theory of separation of powers separates executive, legislative and judicial powers and the importance of the independence of judicial power and the function of judges to judge according to applicable regulations. The development of Legal 
positivism has experienced several effects that are influenced by the social development of society. John Austin's theory of legal positivism about law states that law is an order from a sovereign ruler. Positive law must fulfil the elements of orders, sanctions, obligations, and sovereignty. Proper law is a logical closed system. ${ }^{23}$ Hans Kelsen stated that law as a closed logical system. The law is avoided from non-legal matters such as ethics, sociology, politics. ${ }^{24}$ John Austin and Hans Kelsen stated that the ultimate goal of legal positivism is legal certainty. ${ }^{25}$ Legal Realism in America is one of the basic teachings that states that judges must be active in making decisions. It means that judges not only focus on the formulation of laws and regulations but also pay attention to non-legal factors, namely moral, culture, and social life. ${ }^{26}$

Oliver Wendell Holmes states that law works under concrete events that arise, and the Prophecies of what the courts will do, in fact, and nothing more pretentious, are what the law means it. Judges' role is essential because in deciding cases, one should not rely solely on positive law but must also find the fundamental laws in life to become the basis for decisions. ${ }^{27}$ The teaching of Legal Realism or functional jurisprudence does not ignore the normative-deductive and doctrinal nature of legal studies. It only wants to affirm that every creation of law in concreto always occurs what is called judgments, which means decisions infiltrated by personal considerations which are extra-legal. Roscoe Pound, who teaches sociological jurisprudence, recommends making judgments so that laws and legal decisions are functional in society and proactive in society's engineering changes. ${ }^{28}$ The judge seeks to make substantive justice decisions in the State Administration Court by expanding the dominus litis paradigm. By being active in written legal procedures and focusing on the thought that the judge is a social being, he should need to leave the court building. ${ }^{29}$

In the judicial process, judges are obligated to uphold law and justice and examine and resolve disputes according to specific realities and substantive justice. ${ }^{30}$ The law is always evolving and is a reflection of society.

\section{Joko Santosa v. Head of the Surakarta Integrated Investment and Licensing Board Case}

We can see the Judge's Decision on Case Number 062/G/LH/2016/PTUN. SMG between Joko Santosa (plaintiff) v. The head of the Surakarta Integrated Investment and Licensing Board only considered applying formal legal certainty. In that case, the plaintiff was concerned that negative impacts would arise in other areas that have built multi-story buildings and large-scale business premises, such as drought in wells, air pollution, and B3 waste due to hospital construction. However, the Judge's Decision stated that the plaintiff had no direct interest in the issuance of

23 Widodo Dwi Putro, Mengkritisi Positivisme Hukum: Langkah Awal Memasuki Diskursus Metodologis Dalam Penelitian Hukum (Jakarta: Yayasan Pustaka Obor Indonesia, 2011).

24 Muchammad Ali Safa'at, HLA Hart: Konsep Hukum (Jakarta: Konstitusi Press, 2016).

25 Brian Z. Tamanaha, A Realistic Theory of Law (London: Cambridge, 2017).

26 Atip Latipulhayat, 'Khazanah: Mochtar Kusumaatmadja', Padjadjaran Journal of Law, 1.3 (2014), 629.

27 Brian Z. Tamanaha, A General Jurisprudence for Law and Society (London: Oxford University Press, 2016).

28 Soetandyo Wignosoebroto, Ragam-Ragam Penelitian Hukum Dalam Metode Peneltiian Hukum Konstelasi Dan Refleksi (Jakarta: Yayasan Pustaka Obor Indonesia, 2011).

29 Boy Nurdin, Kedudukan Dan Fungsi Hakim Dalam Penegakan Hukum Di Indonesia (Bandung: Alumni, 2012).

30 Bambang Sutiyoso, 'Mencari Format Ideal Keadilan Putusan Dalam Peradilan', Jurnal Hukum Ius Quia Iustum, 17.2 (2010), 217-32. 
the Decree of the Head of the Surakarta Integrated Investment and Licensing Board, and the lawsuit was only a concern that had not yet occurred..$^{31}$

Based on the judge's decision on that case, we can analyse:

1. Whereas according to Article 53 paragraph (1) of Law Number 9 of 2004 states that "Individuals or civil legal entities who feel that a state administrative decision has harmed their interests can file a written lawsuit to the competent court containing demands for state administrative decisions. Which is disputed is declared cancelled... ". Based on these provisions, we can analyse that the plaintiff is a legal subject who feels that his interests have been harmed by the issuance of a decision letter from the defendant, namely through evidence in the form of the plaintiff's Identity Card whose address is in the same area as the location of activity.

2. Judge's decision on case number 062/G/LH/2016/PTUN. SMG also stated that the plaintiff's lawsuit was premature and concerns the negative impact had yet to occur. We can analyse that the provisions of Article 62 paragraph (1) letter e of Law Number 9 of 2004 state that a lawsuit cannot be accepted if one of the claims is filed prematurely. Judges can use the principle of dominus litis by looking for evidence. Letter from the Head of the Surakarta City Environmental Agency on recommendations for Environmental Feasibility, Business, Hospital Activities, Hotels, Educational Facilities and Supporting Facilities to the Mayor of Surakarta states that "the initiator is responsible for overcoming the negative impacts that will arise from the planned activities." Therefore, the plaintiff obtained a legal basis related to the defendant's responsibility in the event of a negative impact from the activities carried out. Article 53 paragraph (2) of Law Number 9 of 2004 also states that "so that the State Administration Decree (environmental permit) is declared null and void with or without compensation".

It means that although state administrative official permits an ecological business. In the end, it causes environmental pollution to the detriment of the interests of individuals or civil legal entities; a lawsuit can file at the state administrative court for cancellation. ${ }^{32}$

WALHI v. Head of the Patient Integrated Permit Service Office acting on behalf of Semen Gresik Case In legal considerations, judges use socio-cultural and socio-legal approaches. The judge considered that environmental management in the Kars area for the Samin community's survival and the attachment between the Samin community and the surrounding environment were nonlegal factors that had an essential role in forming laws. The decision emphasises the importance of non-legal factors as one of the legal considerations that shows that judges are trying to think socio-legally and progressively and focus on laws and regulations and consider socio-cultural factors (living law) as legal considerations in resolving a dispute.

Judges considerations using a socio-legal approach that is dynamic evolutionary to give substantive fair decisions. With the progress of the judges' judgment, we can analyse that in addition to the formal procedures that must be fulfilled by the defendant, there are other factors

31 Decision Number 062/G/LH/2016/PTUN.SMG Between Joko Santosa (Plaintiff) v. Head of the Surakarta Integrated Investment and Licensing Agency.

32 A'an Afendi, 'Penyelesaian Sengketa Lingkungan Melalui Peradilan Tata Usaha Negara', Jurnal Perspektif, XVIII.1 (2013), 16. 
beyond the law that the defendant must consider. Another factor is the Samin indigenous people's attachment to the environment, views, teachings, religion, culture, and distinctive characteristics. If there is damage to the ecosystem, this will significantly affect daily life, including economic and cultural influences.

Socio-cultural multidisciplinary study in legal reasoning by considering that the Samin people's interests have a living law/unwritten law that must be respected and customary law in Indonesia. Protection of indigenous peoples is clearly stated in Article 18 B paragraph (2), Article 28 I paragraph (3) of The 1945 Constitution of the Republic of Indonesia, and Article 5 in Law Number 39 of 1999 on Human Rights.

We can check the Dominus Litis principle from legal considerations, which state that “...even though several formal procedures have been passed, another important procedure that must be followed is whether or not there is community participation, namely conducting a public hearing when the object of the dispute is not yet a quo published..."

In practice, the dominus litis principle is often hampered due to theoretical constraints, such as the affirmative proof system theory and juridical aspects. Also, formulation of provisions regulating the principle of judge activeness and operational constraints, namely constraints arising from the implementation of proceedings in court because incomplete regulations and the formulation of arguments that are understood and the judges are less creative, such as the principle of environmentally sustainable development. ${ }^{33}$

The societies are not only looking for procedural justice, but they need substantive justice more. Judges at the State Administrative Court should develop or expand the principle of active judges, namely that judges are not limited to being used in processes regulated in statutory regulations, ${ }^{34}$ however, judges need to be active in making legal discoveries which are manifested in the section on the legal judgment in decisions. ${ }^{35}$

In resolving these disputes, the judges must be smart, creative, and innovative in their thinking. Based on the study relating to their reasoning, it is interesting to adopt Ntonius Sudirman's opinion, which is reported in simple terms. Behavioural jurisprudence is the analysis of judges' actual attitude during the judicial process. These behaviours are based on the interactions and relations of those involved in decision-making. It is not focused on any written law and formal verdict, instead it is centred on the attitude of the judges and those involved in specific social roles during the passing of legal verdicts. ${ }^{36}$

These changes are significant in practice because they are related to the dynamic development of society and the law and increasingly complex problems. Anthon F Susanto stated that the change in questionable behaviour is expected to provide a holistic understanding of issues (criminal, state administration) regarding the structure, culture, and model of rules and is also

33 Gede Putera Perbawa, 'Kebijakan Hukum Pidana Terhadap Eksistensi Asas Dominus Litis Dalam Perspektif Profesionalisme Dan Proporsionalisme Jaksa Penuntut Umum', Arena Hukum, 7.3 (2014), 325-42.

34 Aju Putrijanti, 'Prinsip Hakim Aktif (Domini Litis Principle) Dalam Peradilan Tata Usaha Negara', MasalahMasalah Hukum, 42.3 (2013), 320-28.

35 Martinus Sardi and Fatimatuz Zuhro Nurhidayatuloh, Febrian, Achmad Romsan, Annalisa Yahanan, 'Forsaking Equality: Examine Indonesia's State Responsibility On Polygamy To The Marriage Right In CEDAW', Jurnal Dinamika Hukum, 18.2 (2018), 182-93.

36 Antonius Sudirman, Hati Nurani Hakim Dan Putusannya Suatu Pendekatan Dari Perspektif Ilmu Hukum Perilaku (Behavioral Jurisprudence) (Bandung: Citra Aditya Bakti, 2007). 
expected to create judicial intelligence in this era of enlightenment. The legal apparatus does not only function according to rules. Instead, it is logical and rational and based on emotions to recognise patterns and develop habits that can grasp the realities faced ultimately. Besides, this goal is intended towards a complete and holistic understanding, namely "meaningful context". ${ }^{37}$ Consequently, it is time for the practising judges to abandon the old method, which based on the law alone, as well as the logical, linear and rational mindset. It should also adopt the holistic and ecological development of legal science, thereby being able to resolve disputes in a fairly acceptable manner by the community.

It draws on the idea of Satjipto Rahardjo, which always offers input or solutions to the legal problems in Indonesia by considering the progressive law faced in a positive-legalistic manner. In progressive laws, the texts are read and applied like a machine. Instead, it involves human actions or efforts. This method is energy-draining, both in thought, empathy, and courage. It is non-linear because of human actions and efforts. The inclusion or involvement of these factors causes the law to be full of creativity and choices (Satjipto Rahardjo 2009). ${ }^{38}$ Furthermore, Satjipto reported that it is interpreted as the testing of legal ability and presumed that the law's enactment and implementation bring justice to society.

Consequently, adhering to the law using only text does not automatically imply justice; therefore, it is divided into text (formal or legal justice) and real justice (substantial justice). Paul Scholten reported that justice is indeed the law, although it still needs to be discovered (het recht is in de wet, maar het moet nog gevonden warden). Consequently, adhering to the law is not the same as implementing it. Instead, it attempts to bring out the stored justice. It merely implies testing the limits of legal capacity.

The shifting paradigm of the dominus litis principle in legal considerations is actively using the juridical-legal positivism aspects and conducting legal reasoning using socio-legal and sociocultural factors. The use of socio-legal and socio-cultural factors due to environmental problems is a crucial and actual problem. It involves various interests so that it requires a multidisciplinary study with a progressive legal interpretation approach that is evolutive-dynamic.

\section{CONCLUSIONS}

The shifting paradigm of the dominus litis principle in legal considerations is actively using the juridical-legal positivism factors. It needs to be expanded by conducting legal reasoning using socio-legal and socio-cultural factors. The use of socio-legal and socio-cultural elements because of environmental problems is a crucial and actual problem and involves sustainable development issues so that it requires a multidisciplinary study with a progressive legal interpretation approach evolutive-dynamic. The judges' duties are getting tougher daily because the legal issues during court proceedings are increasingly complex. In this regard, when they are resolving disputes, they do not only apply laws or state the provisions because it always appears incomplete, unclear, and does not accommodate all societal problems. The law is not perceived as the only guide for resolving disputes. In disputes accomplishment, judges need to courageously change their mindset in a more advanced or forward-looking manner. They need to be creative and innovative,

\footnotetext{
37 Anthon F. Susanto, Ilmu Hukum Non Sistematik Fondasi Filsafat Pengembangan Ilmu Hukum Indonesia.

38 Satjipto Rahardjo, Penegakan Hukum: Suatu Tinjauan Sosiologis (Yogyakarta: Genta Publishing, 2009).
} 
excluding the hegemony of legal positivism. They play an essential role in resolving disputes. The judge's activeness (dominus litis) needs to be developed in such a way to create balanced objectives between the plaintiff and the defendant as well as achieve true justice in society. They can perceive the reality of the law and its values. Judges are also able to resolve disputes by thinking thoroughly or holistically and, at the same time, take their conscience and empathy into consideration. The movements and changes are centred on the mindset that humans consider the law a paradigm shift in dispute accomplishment.

\section{REFERENCES}

Afendi, A'an, 'Penyelesaian Sengketa Lingkungan Melalui Peradilan Tata Usaha Negara', Jurnal Perspektif, XVIII.1 (2013), 16

Ali, Achmad, Menguak Tabir Hukum (Bogor: Ghalia Indonesia, 2008)

Asikin, Amiruddin and Zainal, Pengantar Metode Penelitian Hukum (Jakarta: Rajawali Pers, 2012)

Asrun, A. Muhammad, Krisis Peradilan Mahkamah Agung Di Bawah Soeharto (Jakarta: ELSAM, 2004)

Asshiddiqie, Jimly, Gagasan Konstitusi Sosial (Jakarta: LP3ES, 2015)

Decision Number 062/G/LH/2016/PTUN.SMG Between Joko Santosa (Plaintiff) vs. Head of the Surakarta Integrated Investment and Licensing Agency

Dewi, Sinta, Tinjauan Kritis Atas Perkembangan Hukum Seiring Perkembangan Masyarakat Di Indonesia (Bandung: Widya Padjadjaran, 2009)

Et.All, Firzhal Arzhi Jiwantara., 'The Extension Of Absolute Competence Of State Administrative Court After The Enactment Of Act Number 30 Of 2014 On Government Administration In Indonesia', Journal of Legal, Ethical and Regulatory Issues, 21.2 (2018), 1

Et.All, Wahyu Beny., 'Law Politic Of Administrative Court Judicature In Indonesia', International Journal of Law Recontruction, III.1 (2019), 48

Latipulhayat, Atip, 'Khazanah: Mochtar Kusumaatmadja', Padjadjaran Journal of Law, 1.3 (2014), 629

Mertokusumo, Soedikno, Penemuan Hukum Sebuah Pengantar (Yogyakarta: Universtas Atma Jaya, 2010)

Namlis, Ahmad, 'Dinamika Implementasi Penyelenggaraan Pemerintahan Daerah', Jurnal Kajian Pemerintah: Journal Of Government, Social And Politics, 4.1 (2018)

Nurdin, Boy, Kedudukan Dan Fungsi Hakim Dalam Penegakan Hukum Di Indonesia (Bandung: Alumni, 2012)

Nurhidayatuloh, Febrian, Achmad Romsan, Annalisa Yahanan, Martinus Sardi and Fatimatuz Zuhro, 'Forsaking Equality: Ezamine Indonesia's State Responsibility on Polygamy To The Marriage Right In CEDAW', Jurnal Dinamika Hukum, 18.2 (2018), 182-93

Perbawa, Gede Putera, 'Kebijakan Hukum Pidana Terhadap Eksistensi Asas Dominus Litis Dalam Perspektif Profesionalisme Dan Proporsionalisme Jaksa Penuntut Umum', Arena Hukum, 7.3 (2014), 325-42

Putrijanti, Aju, 'Prinsip Hakim Aktif (Domini Litis Principle) Dalam Peradilan Tata Usaha Negara', Masalah-Masalah Hukum, 42.3 (2013), 320-28 
Putro, Widodo Dwi, Mengkritisi Positivisme Hukum: Langkah Awal Memasuki Diskursus Metodologis Dalam Penelitian Hukum (Jakarta: Yayasan Pustaka Obor Indonesia, 2011)

Rahardjo, Satjipto, Biarkan Hukum Mengalir Catatan Kritis Tentang Pergulatan Manusia Dan Hukum (Jakarta: Buku Kompas, 2007)

— Lapisan-Lapisan Dalam Studi Hukum (Malang: Bayumedia Publishing, 2008)

— Penegakan Hukum: Suatu Tinjauan Sosiologis (Yogyakarta: Genta Publishing, 2009)

Ridwan, 'Hukum Dan Perubahan Sosial: (Perdebatan Dua Kutub Antara Hukum Sebagai Social Control Dan Hukum Sebagai Social Enginnering)', Jurnal Jurisprudence, 6.1 (2017), 2839

Romana, Francisca, 'Authority Of The Judge Of Administrative Court To Revise The Government Official Decision', Journal of Legal, Ethical and Regulatory Issues, 21.Special Issue (2018), 1

Ruslin, 'An Existence of State Administration Court in Establishing Good Governance', Aloha International Journal of Multidisciplinary Advancement (AIJMU), 1.1 (2019), 2

Sa'ad, Miftah, 'The Schorsing in Implementation of Administrative Decision That Endanger the Environment by Administrative Court', Nagari Law Review, 1.2 (2018), 180

Safa'at, Muchammad Ali, HLA Hart: Konsep Hukum (Jakarta: Konstitusi Press, 2016)

Savitri, Sri Rahayu Oktoberina dan Niken, Butir-Butir Pemikiran Dalam Hukum Memperingati 70 Tahun Prof. Dr. B. Arief Sidharta. SH (Bandung: Refika Aditama, 2008)

Sudirman, Antonius, Hati Nurani Hakim Dan Putusannya Suatu Pendekatan Dari Perspektif Ilmu Hukum Perilaku (Behavioral Jurisprudence) (Bandung: Citra Aditya Bakti, 2007)

Susanto, Anthon F., Ilmu Hukum Non Sistematik Fondasi Filsafat Pengembangan Ilmu Hukum Indonesia (Yogyakarta: Genta Publishing, 2010)

- Wajah Peradilan Kita Konstruksi Sosial Tentang Pnyimpangan. Mekanisme Kontrol Dan Akuntabiltas Peradilan Pidana (Bandung: PT. Refika Aditama, 2004)

Susanto, Otje Salman dan Anthon F, Teori Hukum (Mengingat, Mengumpulkan, Dan Membuka Kembali) (Bandung: Refika Aditama, 2004)

Sutiyoso, Bambang, 'Mencari Format Ideal Keadilan Putusan Dalam Peradilan', Jurnal Hukum Ius Quia Iustum, 17.2 (2010), 217-32

Tamanaha, Brian Z., A General Jurisprudence for Law and Society (London: Oxford University Press, 2016)

—, A Realistic Theory of Law (London: Cambridge, 2017)

Wignjosoeborot, Soetandyo, Pergeseran Paradigma Dalam Kajian-Kajian Ilmu Sosial Dan Hukum (Malang: Setara Press, 2013)

Wignosoebroto, Soetandyo, Ragam-Ragam Penelitian Hukum Dalam Metode Peneltiian Hukum Konstelasi Dan Refleksi (Jakarta: Yayasan Pustaka Obor Indonesia, 2011) 